\section{Systematic literature review of efficacy, safety and tolerability outcomes of chemotherapy regimens in patients with metastatic Merkel cell carcinoma}

\author{
Paul Nghiem ${ }^{* 1}$, Howard L Kaufman², Murtuza Bharmal ${ }^{3}$, Lisa Mahnke ${ }^{4}$, \\ Hemant Phatak ${ }^{5}$ \& Jürgen C Becker ${ }^{6}$
}

\begin{abstract}
Aim: Merkel cell carcinoma (MCC) is a rare neuroendocrine, cutaneous malignancy with poor prognosis once metastasized. The aim of this study was to conduct a systematic literature review to assess clinical outcomes associated with chemotherapy regimens in metastatic MCC. Materials \& methods: Embase ${ }^{\circledR}$, MEDLINE ${ }^{\oplus}$, MEDLINE ${ }^{-}$-In-Process and CENTRAL were searched for studies published in January 2016. Results \& conclusion: Overall, the literature on chemotherapy in patients with metastatic MCC is sparse, with most studies being case series/reports. Across all studies, response rates ranged from 20 to $61 \%$, with higher response rates in first-line setting (53-61\%) versus second-line setting (23-45\%). Among responders, duration of response was short ( $\leq 8$ months) in both first- and second-line settings. There is a need for novel agents that can induce durable responses in metastatic MCC.
\end{abstract}

First draft submitted: 14 February 2017; Accepted for publication: 8 March 2017; Published online: 28 March 2017

Merkel cell carcinoma (MCC), also termed APUDoma of the skin, trabecular cancer or small-cell neuroepithelial tumor of the skin, is a rare neuroendocrine, skin cancer that was first described by Toker in 1972 [1]. MCC, which occurs more frequently in elderly individuals, exhibits aggressive clinical features and is associated with a poor prognosis [2-4]. The overall 5-year survival rate of MCC is $40 \%$ [5].

The oncogenesis of MCC was historically poorly understood; however, recent technology, such as deep transcriptome sequencing, has allowed viral and molecular oncogenic mechanisms to be elucidated, dramatically increasing our understanding of MCC [6]. Nevertheless, the cell of origin of MCC still remains elusive [7]. The etiology is likely multifactorial with general immunosuppression and ultraviolet (UV)-induced local immunosuppression as major risk factors, suggesting that viral factors contribute to the development of MCC [8]. Merkel cell polyomavirus (MCPyV), a DNA virus that integrates into the host genome, is detected in approximately $80 \%$ of MCC cases [9]. However, studies reporting $\mathrm{UV}$-signature mutations in $\mathrm{MCPyV}$-negative MCC indicate that $\mathrm{UV}$ exposure is likely to be key in the pathogenesis of the viral-negative MCC subtypes [10-12].

\footnotetext{
'Division of Dermatology, University of Washington Medical School, Fred Hutchinson Cancer Research Center, Seattle, WA 98195-8050, USA

${ }^{2}$ Rutgers Cancer Institute of New Jersey, New Brunswick, NJ 08903, USA

${ }^{3}$ Merck KGaA, Darmstadt, Germany

${ }^{4}$ Global Research and Early Development, EMD Serono, Billerica, Boston, MA 01821, USA

${ }^{5}$ Health Economics and Outcomes Research, EMD Serono, Rockland, MA 02370, USA

${ }^{6}$ Translational Skin Cancer Research, German Cancer Consortium (DKTK), Partner site Essen Düsseldorf, University Hospital Essen,

Essen, Germany

*Author for correspondence: pnghiem@uw.edu
}

\section{KEYWORDS}

- checkpoint inhibitors

- chemotherapy

- immunotherapy • Merkel cell carcinoma $\bullet$ metastasis

- systematic literature review 
Patients with MCC usually present with a firm, painless, rapidly enlarging, cutaneous tumor nodule that is typically dome shaped; superficial ulceration is rare, but may also be present, particularly in the later stages of disease $[4,13]$. MCC may grow rapidly on chronically sun-exposed skin, and once MCC develops, distant metastases typically arise within the first 3 years following diagnosis [14]. According to the 2010 American Joint Commission on Cancer (AJCC) classification, patients with MCC are categorized into different stages according to their clinical characteristics - stage I: patients with a primary tumor size of $\leq 2 \mathrm{~cm}$; stage II: patients with a primary tumor size of $>2 \mathrm{~cm}$ ); stage III: patients with positive nodal disease; and stage IV: patients with distant metastases [15]. Prognosis in patients with MCC is poor [2-4]; the overall relative 5-year survival rate among all patients with MCC is $54 \%$ compared with age- and sex-matched population data (calculated as the ratio of the observed and the expected average of the population-based probabilities for each patient in the cohort), falling to $18 \%$ in patients with stage IV metastatic disease [5]. Similar findings were reported in an analysis of a National Cancer Data Base Participant User File with follow-up and staging data (1998-2012) of 9387 MCC where the 5-year overall survival (OS) was 51\% for local disease, 35\% for nodal disease and 14\% for distant metastatic disease [16].

There are currently no approved therapies for patients with MCC, and no consensus exists on the most effective treatment strategy, particularly in advanced tumor stages [17,18]. The choice of treatment depends on the stage of the disease, the tumor location and any comorbid conditions [18]. At early stages, surgery is the primary treatment modality with sentinel lymph node biopsy. Radiation therapy can be considered for primary therapy in patients who are not surgical candidates, while chemotherapy is reserved for metastatic disease or only as palliative therapy in symptomatic patients [18].

The National Comprehensive Cancer Network guidelines state that MCC is a chemotherapy-sensitive tumor, but the use of chemotherapy in these patients is not well defined, and guidelines recommend participation in clinical trials for patients with metastatic MCC $[18,19]$. Treatment options recommended in guidelines are based on treatments for small-cell lung carcinoma due to the similar neuroendocrine properties to MCC [18,19]. Commonly used regimens include a platinum agent \pm etoposide phosphate, cyclophosphamide, doxorubicin (or epirubicin) and vincristine, and topotecan [18,19]. However, no studies have directly evaluated the efficacy of one regimen over another, and most are associated with significant toxicity $[18,20]$. Although surgery and/or radiation therapy may be curative for patients with locoregional MCC without distant metastases, recurrences are common and often incurable [21]. Even in patients with local or regional disease, approximately $48 \%$ of patients ultimately develop recurrent disease. Studies have shown that among patients who experienced recurrence, the median time between diagnosis and recurrence is 9 months [14,22].

Currently, the literature on the use of chemotherapy in advanced/metastatic MCC is inadequate to definitively assess whether chemotherapeutic regimens improve either progression-free survival (PFS) or OS in patients with MCC, and thus their routine use in MCC cannot be recommended on the basis of the current evidence [18]. Thus, the aim of this study was to conduct a systematic literature review of available studies or case series assessing the efficacy, health-related quality of life (HRQoL), safety and tolerability outcomes associated with chemotherapy regimens for the treatment of patients with metastatic MCC, to inform the current clinical landscape in metastatic MCC and to highlight any evidence gaps. As immune therapies are now being explored in MCC, it is important to document what is currently known regarding traditional chemotherapeutic approaches for MCC to provide a context for discussion.

\section{Materials \& methods}

A systematic literature review of Embase ${ }^{\circledR}$, MEDLINE $^{\circledR}$, MEDLINE $^{\circledR}$-In-Process and CENTRAL was conducted from database inception to January 2016 to capture efficacy, HRQoL and safety/tolerability outcomes of systemic interventions in patients with metastatic MCC. Bibliographic searching for potentially relevant publications and ongoing trials was also conducted in October 2015 (The Cochrane Database of Systematic Reviews [23], Database of Abstracts of Reviews of Effects [24], Orphanet website [25] and GLOBOCAN website [26]). Apart from databases, conference abstracts were hand-searched from 2011 to 2015 to retrieve studies that have not yet been published in journals as full-text 
articles or to supplement results of previously published studies (excluding listings in Emabse [27]): American Academy of Dermatology [28], American Head and Neck Society [29], American Society of Clinical Oncology [30], British Association of Dermatologists [31], European Association of Dermato Oncology [32], European Cancer Congress/European Society for Medical Oncology [33,34], International Federation of Head and Neck Oncologic Societies [35], International Society For Pharmacoeconomics and Outcomes Research [36], Society for Melanoma Research [37] and World Congress of Dermatology [38].

To be included in this review, studies had to meet the eligibility criteria presented in Box 1 . As the objective of this review was to evaluate outcomes with chemotherapy regimens in patients with MCC, studies that did not evaluate chemotherapy regimens were not covered systematically. Due to the limited evidence based on prospective clinical trials retrieved in patients with distant metastatic MCC, both case series and case reports were also included in this review. Since Tai et al. [20], one of the seminal publications for this review, had already included case reports published prior to 1997, we included case reports published from January 1997 to January 2016 to avoid double counting. Included studies were classified based on the type of metastasis:

- Distant metastases: These refer to cancer that has spread from the original (primary) tumor to distant organs or distant lymph nodes;

- Regional metastases: These refer to cancer that has grown into surrounding tissues or organs or lymph nodes;

- Unclear/mixed metastases: These refer to studies where it was difficult to categorize cancer into distant or regional metastases.

Screening of studies and data extraction was conducted by two independent reviewers, with any discrepancies reconciled by a third independent reviewer.

\section{Results}

\section{- Characteristics of the included studies}

Searches of the literature databases, screening of conference abstracts and bibliographic searches resulted in the inclusion of a total of 45 studies from 47 publications that evaluated pharmacological interventions in patients with MCC. Ten of the 45 studies did not evaluate chemotherapy regimens (these included targeted therapies or immunotherapies) and were therefore excluded from the review. Of the 35 studies included in the review, 33 studies reported data from patients with distant metastases; 3 reported data for metastatic MCC not differentiating between distant and locoregional diseases; and 3 reported data from patients with regional metastases (Figure 1) (the number of studies categorized by types of metastases exceeds the total number of included studies because some studies reported outcomes for $\geq 1$ type of metastases). Table 1 presents the list of the 35 studies included in the review.

The majority of studies reporting outcomes in patients with distant metastases were case reports $(n=17)$ with 12 case series, and 5 retrospective studies/literature reviews. Three of these were literature reviews that included case series/reports; however, due to the scarcity of data, these were included in this review [20,41,42]. Notably, a few of the case series retrieved in this review were also captured in the previous literature reviews and have been double counted in our review; these are indicated in Table 1. The reason for including these case series was to extract details not provided in the previous literature reviews, such as patient populations, dosing regimens and survival outcomes.

In studies reporting outcomes in patients with regional metastases, one study was a retrospective study/literature review and the other two studies were case series. Three of the studies for which the type of metastases was unclear (referred to as 'metastatic MCC') were retrospective studies/ literature reviews.

Across the included studies, the most commonly reported outcomes were objective response rate (ORR) that includes complete response (CR) and partial response (PR), followed by overall mortality and median OS. Most of the included studies did not specify the criteria used to assess ORR, with only four studies specifically mentioning Response Evaluation Criteria In Solid Tumors (RECIST) criteria [39,40,51,59]. Other reported outcomes included duration of response (DoR), safety, median PFS, and both OS and PFS rates. None of the included studies reported data on quality of life in patients with metastatic MCC.

\section{- Patients \& disease characteristics}

Based on the retrospective studies/literature reviews and case series, the median age (where reported) ranged from 54 to 78.5 years. The proportion of men was higher than the proportion 
Box 1. Key eligibility criteria for the systematic literature review.

\section{Inclusion criteria}

\section{Population:}

- Age: adults aged $\geq 18$ years

- Gender: any

- Race: any

- Disease: metastatic MCC

- Distant metastatic MCC (including metastases to distant lymph nodes)

- Regional or lymph node metastatic MCC

- Inclusion of case reports was restricted to patients with distant metastases

\section{Intervention:}

- Any pharmacological intervention

Study design:

- All RCTs (irrespective of blinding status)

- Nonrandomized controlled trials

- Single arm trials

- Observational studies (retrospective analysis, prospective studies, cohort studies, case-control studies, case series and case reports)

- Language restrictions:

- Both English and non-English language studies for all study designs except case reports

- Inclusion of case reports was restricted to studies published in English language

- Exclusion criteria

Intervention:

- Studies investigating the role of radiotherapy, chemo-radiotherapy, hormonal therapy or surgery were excluded

- Studies investigating the role of maintenance/consolidation therapy after surgery were excluded

- Adjuvant or neoadjuvant therapy was excluded

- Studies investigating the role of targeted therapies were excluded

Subgroup analysis:

- No subgroup analysis

MCC: Merkel cell carcinoma; RCT: Randomized controlled trial.
Distant metastatic MCC

A total of 5 retrospective studies/literature reviews assessing patients with distant metastases were included in the review. Across these five studies, ORR in both the second-line and firstline setting ranged from $23 \%$ in the second-line and $52-61 \%$ in the first-line, or mostly first-line, as some studies did not stratify results by line of therapy (CR: 3-37\%; PR: 20-40\%) [20,39-42]. In studies that specified line of therapy, response rates were higher in the first-line setting (ORR: $52-57 \%)[39,41]$ compared with the second-line setting (ORR: 23\%) [39]. However, irrespective of line of therapy, responses to chemotherapy were not durable and only lasting up to a median of 6 months (reported in three studies) [20,39,40]. Among responders, median DoR of one study was reported to be higher among patients receiving second-line therapy compared with first-line therapy (4.2 vs 2.8 months) [39]. However, this should be interpreted with caution due to the small number of responders, and outcomes may have been affected by selection bias in the second-line setting. Median PFS was short regardless of the line of therapy; 3.1 months in the firstline setting versus 2 months in the second-line setting [39]. Median OS was reported in two of the five retrospective studies/literature reviews, ranging from 9 to 9.5 months $[39,41]$.

Similar findings were reported in case series, where a higher proportion of patients in the first-line setting achieved CR compared with patients receiving second-line therapy. Similar to findings from retrospective studies/literature reviews, DoR was higher among patients receiving first-line therapy compared with those receiving second-line therapy (4 vs 2 months).

None of the included studies were designed to compare differences in response among different interventions.

A summary of response rates from the included case reports has been presented in Table 3. In agreement with the retrospective studies/literature reviews, findings from the small-sized case reports may suggest that the proportion of patients achieving a PR was higher among patients receiving chemotherapy in the first-line setting $(24 \%$ or 4 of 17 patients) compared with the second-line setting $(20 \%$ or 1 of 5 patients) $[64,67,68]$. None of the patients treated in the third- or fourth-line settings achieved a CR [59,63]. The proportion of patients achieving a CR was slightly higher among those receiving platinum-containing 

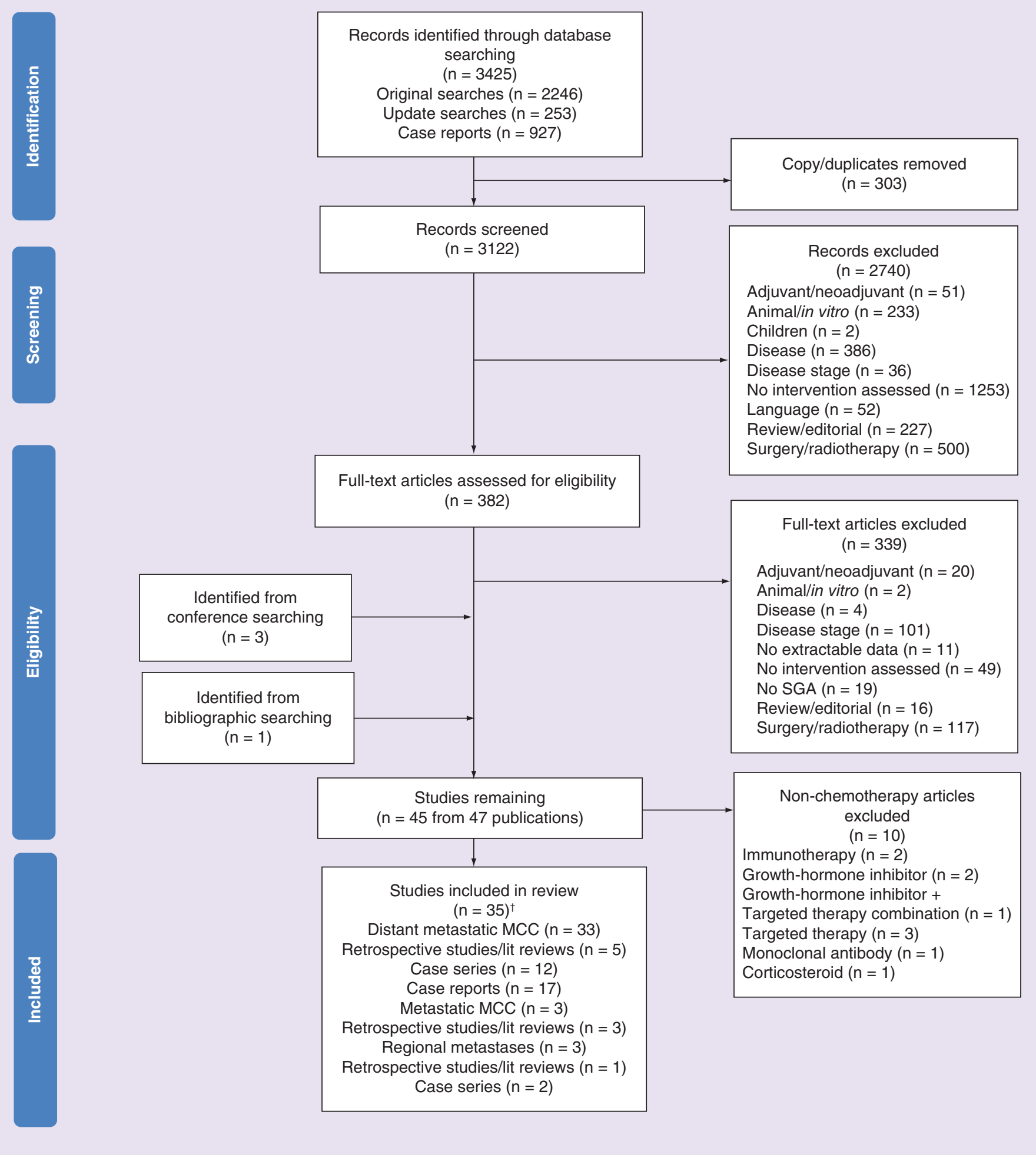

Figure 1. Preferred reporting items for systematic reviews and meta-analyses study flow diagram.

tThe number of studies categorized into different types of metastases exceeds the total number of included studies $(n=35)$ as some studies reported outcomes for $\geq 1$ type of metastases.

MCC: Merkel cell carcinoma; PRISMA: Preferred reporting items for systematic reviews and meta-analyses; SGA: Subjective global assessment. 
Table 1. List of included studies.

\begin{tabular}{|c|c|c|c|c|c|c|}
\hline $\begin{array}{l}\text { Study } \\
\text { (year) }\end{array}$ & $\begin{array}{l}\text { Has this study } \\
\text { been included } \\
\text { in another } \\
\text { review? (Yes/no) }\end{array}$ & Study design & $\begin{array}{l}\text { Line of } \\
\text { therapy }\end{array}$ & $\begin{array}{l}\text { Study } \\
\text { population } \\
\text { (n) }\end{array}$ & Intervention & Ref. \\
\hline \multicolumn{7}{|c|}{ Distant metastases $(n=33)$} \\
\hline \multicolumn{7}{|c|}{ Retrospective studies/literature reviews ( $n=5$ ) } \\
\hline $\begin{array}{l}\text { lyer et al. } \\
(2014)^{\ddagger}\end{array}$ & No & $\begin{array}{l}\text { Retrospective } \\
\text { observational study }\end{array}$ & $\begin{array}{l}\text { First and } \\
\text { second line }\end{array}$ & 62 & $\begin{array}{l}\text { - Platinum plus etoposide; topotecan; platin + VP16, } \\
\text { others (carboplatin, etoposide and gemcitabine) }\end{array}$ & {$[39]^{\ddagger}$} \\
\hline $\begin{array}{l}\text { Satpute } \\
\text { et al. (2014) }\end{array}$ & No & $\begin{array}{l}\text { Retrospective } \\
\text { observational study }\end{array}$ & Unclear & 13 & $\begin{array}{l}\text { - Carboplatin + etoposide; cisplatin + etoposide; } \\
\text { carboplatin + taxol }\end{array}$ & [40] \\
\hline $\begin{array}{l}\text { Sharma } \\
\text { et al. (1991) }\end{array}$ & Yes $[20,41]$ & $\begin{array}{l}\text { Case report and } \\
\text { review of literature }\end{array}$ & Unclear & 46 & $\begin{array}{l}\text { - Doxorubicin/cyclophosphamide regimens, } \\
\text { platinum regimens and miscellaneous regimens }\end{array}$ & [42] \\
\hline $\begin{array}{l}\text { Tai et al. } \\
(2000)\end{array}$ & No & $\begin{array}{l}\text { Case series and } \\
\text { review of literature }\end{array}$ & Unclear & 103 & $\begin{array}{l}\text { - Cyclophosphamide/ doxorubicin (or epirubicin)/ } \\
\text { vincristine combination } \pm \text { prednisone, etoposide/ } \\
\text { cisplatin (or carboplatin) }\end{array}$ & [20] \\
\hline $\begin{array}{l}\text { Voog et al. } \\
\text { (1999) }\end{array}$ & No & $\begin{array}{l}\text { Case series and } \\
\text { review of literature }\end{array}$ & $\begin{array}{l}\text { First, second } \\
\text { and third } \\
\text { line }\end{array}$ & $72^{\S}$ & $\begin{array}{l}\text { - Different chemotherapy regimens were used. Most } \\
\text { commonly used were } \\
\text { - CAV; platinum + etoposide; doxorubicin + cisplatin }\end{array}$ & [41] \\
\hline \multicolumn{7}{|c|}{ Case series $(n=12)$} \\
\hline $\begin{array}{l}\text { Bourne and } \\
\text { O'Rourke } \\
\text { (1988) }\end{array}$ & Yes [42] & Case series & Unclear & 4 & $\begin{array}{l}\text { - Cyclophosphamide }+ \text { doxorubicin }+ \text { vincristine }+ \\
\text { prednisolone }\end{array}$ & [43] \\
\hline $\begin{array}{l}\text { Boyle et al. } \\
\text { (1995) }\end{array}$ & Yes $[20,41]$ & Case series & Unclear & 13 & $\begin{array}{l}\text { - Chlorambucil or mitozantrone alone or etoposide, } \\
\text { carboplatin, cyclophosphamide, chlorambucil, } \\
\text { vincristine, doxorubicin and epirubicin in various } \\
\text { combinations. Four patients received radiotherapy in } \\
\text { combination with chemotherapy }\end{array}$ & [44] \\
\hline $\begin{array}{l}\text { Crown et al. } \\
\text { (1991) }\end{array}$ & Yes $[20,41]$ & Case series & Unclear & 9 & $\begin{array}{l}\text { - Different combinations of cyclophosphamide, } \\
\text { doxorubicin, vincristine, cisplatin, streptozotocin, } \\
\text { fluorouracil, leucovorin, prednisone, methotrexate, } \\
\text { melphalan and lomustine }\end{array}$ & {$[45]$} \\
\hline $\begin{array}{l}\text { Fenig et al. } \\
\text { (1993) }\end{array}$ & Yes [41] & Case series & $\begin{array}{l}\text { First and } \\
\text { second line }\end{array}$ & 2 & $\begin{array}{l}\text { - Cisplatin -VP } 16 \text { and cyclophosphamide, } \\
\text { methotrexate and 5-flurouracil + VP-16 }\end{array}$ & [46] \\
\hline $\begin{array}{l}\text { Feun et al. } \\
\text { (1988) }\end{array}$ & Yes $[20,41,42]$ & Case series & Unclear & $6^{n}$ & $\begin{array}{l}\text { - Chemotherapy regimens included a combination } \\
\text { of melphalan, dactinomycin and nitrogen mustard, } \\
\text { methotrexate, cisplatin and bleomycin, intra-arterial } \\
\text { cisplatin and adriamycin-containing regimen }\end{array}$ & {$[47]$} \\
\hline $\begin{array}{l}\text { Grosh et al. } \\
\text { (1987) }\end{array}$ & Yes $[20,41,42]$ & Case series & $\begin{array}{l}\text { First and } \\
\text { second line }\end{array}$ & 4 & - Cyclophosphamide + doxorubicin + vincristine & [48] \\
\hline $\begin{array}{l}\text { Pectasides } \\
\text { et al. (2006) }\end{array}$ & No & Case series & $\begin{array}{l}\text { First and } \\
\text { second line }\end{array}$ & $2^{\#}$ & $\begin{array}{l}\text { - 1L: carboplatin, etoposide (VP-16) } \\
\text { - 2L: cisplatin + ifosfamide + epirubicin }\end{array}$ & [49] \\
\hline $\begin{array}{l}\text { Redmond } \\
\text { et al. (1991) }\end{array}$ & Yes $[20,41]$ & Case series & Unclear & 5 & $\begin{array}{l}\text { - Cisplatin + etoposide; cisplatin + etoposide } \\
\text { + cyclophosphamide, cyclophosphamide + } \\
\text { doxorubicin + vincristine }\end{array}$ & [50] \\
\hline $\begin{array}{l}\text { Schlaak } \\
\text { et al. (2012) }\end{array}$ & No & Case series & $\begin{array}{l}\text { First and } \\
\text { second line }\end{array}$ & 4 & $\begin{array}{l}\text { - Etoposide } 100 \text { mg per day; carboplatin, etoposide } \\
\text { - Patients also received additional irradiations during } \\
\text { chemotherapeutic treatment }\end{array}$ & [51] \\
\hline \multicolumn{7}{|c|}{$\begin{array}{l}\text { TStudies that reported outcomes for } \geq 1 \text { type of metastases are repeated across multiple rows. } \\
\text { ftSince conducting our review, this study has been published as a full-text article [73]. } \\
\text { sOf the } 101 \text { patients included in the study, } 72 \text { had distant metastases and } 29 \text { had regional or nodal metastases. } \\
\text { "Of the } 13 \text { patients included in the study, } 6 \text { had distant metastases and } 7 \text { had regional or nodal metastases. } \\
\text { "Of the six patients included in the study, two had distant metastases and four had regional or nodal metastases. } \\
\text { ABSCT: Autologous blood stem cell transplantation; AUC: Area under the plasma concentration versus time curve; CAV: Cyclophosphamide, doxorubicin and vincristine; } \\
\text { DTIC: Dacarbazine; MCC: Merkel cell carcinoma; PEl: Cisplatin, etoposide and ifosfamide. }\end{array}$} \\
\hline
\end{tabular}


Table 1. List of included studies (cont.).

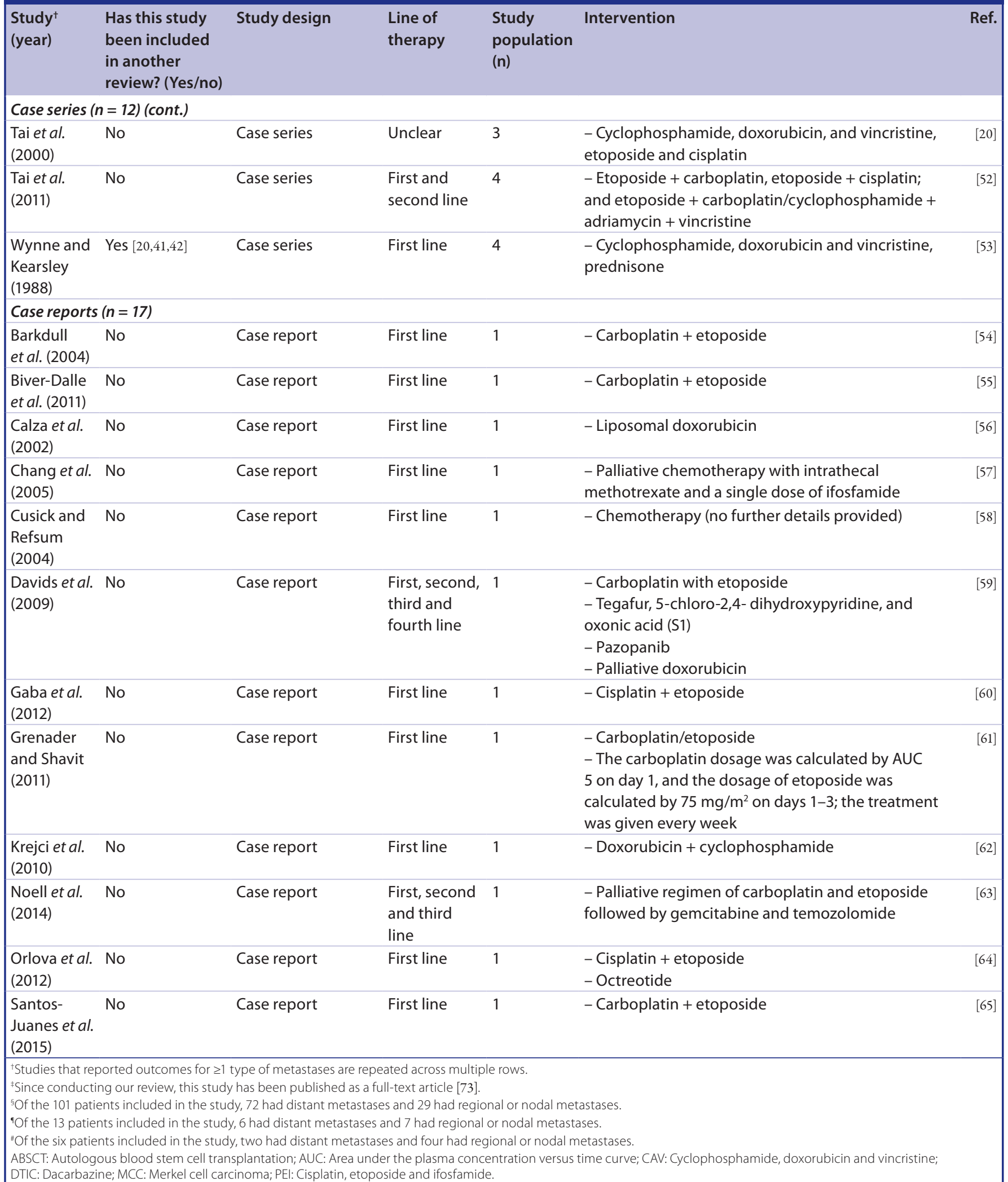




\section{Table 1. List of included studies (cont.).}

\begin{tabular}{|c|c|c|c|c|c|c|}
\hline $\begin{array}{l}\text { Study } \\
\text { (year) }\end{array}$ & $\begin{array}{l}\text { Has this study } \\
\text { been included } \\
\text { in another } \\
\text { review? (Yes/no) }\end{array}$ & Study design & $\begin{array}{l}\text { Line of } \\
\text { therapy }\end{array}$ & $\begin{array}{l}\text { Study } \\
\text { population } \\
\text { (n) }\end{array}$ & Intervention & Ref. \\
\hline \multicolumn{7}{|c|}{ Case reports ( $n=17)$ (cont.) } \\
\hline $\begin{array}{l}\text { Shah et al. } \\
\text { (2012) }\end{array}$ & No & Case report & $\begin{array}{l}\text { First and } \\
\text { second line }\end{array}$ & 1 & $\begin{array}{l}\text { - Palliative chemotherapy with carboplatin and } \\
\text { etoposide } \\
\text { - Second-line therapy with TS-1 }\end{array}$ & [66] \\
\hline $\begin{array}{l}\text { Tanemura } \\
\text { et al. (2012) }\end{array}$ & No & Case report & First line & 1 & - Carboplatin + etoposide & [67] \\
\hline $\begin{array}{l}\text { Waldmann } \\
\text { et al. (2000) }\end{array}$ & No & Case report & $\begin{array}{l}\text { First and } \\
\text { second line }\end{array}$ & 1 & $\begin{array}{l}\text { - Polychemotherapy (cisplatin + doxorubicin + } \\
\text { etoposide + bleomycin) } \\
\text { - High-dose polychemotherapy according to the PEI } \\
\text { regimen (ifosfamide + carboplatin + etoposide) and } \\
\text { ABSCT }\end{array}$ & [68] \\
\hline $\begin{array}{l}\text { Wang et al. } \\
\text { (2014) }\end{array}$ & No & Case report & First line & 1 & - Palliative regimen of carboplatin and etoposide & [69] \\
\hline $\begin{array}{l}\text { Yamana } \\
\text { et al. (2004) }\end{array}$ & No & Case report & $\begin{array}{l}\text { First and } \\
\text { second line }\end{array}$ & 1 & - Cisplatin with or without etoposide & [70] \\
\hline \multicolumn{7}{|c|}{ Metastatic MCC $(n=3)$} \\
\hline \multicolumn{7}{|c|}{ Retrospective studies/literature reviews $(n=3)$} \\
\hline $\begin{array}{l}\text { Di et al. } \\
\text { (1995) }\end{array}$ & No & Single-arm study & Unclear & 5 & - Fluorouracil, epirubicin and DTIC & [71] \\
\hline $\begin{array}{l}\text { Savage } \\
\text { et al. (1997) }\end{array}$ & Yes [20] & $\begin{array}{l}\text { Retrospective } \\
\text { observational study }\end{array}$ & Unclear & 4 & $\begin{array}{l}\text { - Combination of cyclophosphamide, vincristine } \\
\text { and doxorubicin. Other chemotherapy regimens } \\
\text { used were oral etoposide, epirubicin and } \\
\text { cyclophosphamide, and cyclophosphamide once }\end{array}$ & [72] \\
\hline $\begin{array}{l}\text { Voog et al. } \\
\text { (1999) }\end{array}$ & No & $\begin{array}{l}\text { Case series and } \\
\text { review of literature }\end{array}$ & $\begin{array}{l}\text { First, second } \\
\text { and third } \\
\text { line }\end{array}$ & $101^{\S}$ & - Different chemotherapy regimens were used & [41] \\
\hline \multicolumn{7}{|c|}{ Regional or nodal metastases $(n=3)$} \\
\hline \multicolumn{7}{|c|}{ Retrospective studies/literature reviews $(n=1)$} \\
\hline $\begin{array}{l}\text { Voog et al. } \\
\text { (1999) }\end{array}$ & No & $\begin{array}{l}\text { Case series and } \\
\text { review of literature }\end{array}$ & $\begin{array}{l}\text { First, second } \\
\text { and third } \\
\text { line }\end{array}$ & $29^{\S}$ & $\begin{array}{l}\text { - Different chemotherapy regimens were used. Most } \\
\text { commonly used were CAV, platinum+etoposide and } \\
\text { doxorubicin + cisplatin }\end{array}$ & [41] \\
\hline \multicolumn{7}{|c|}{ Case series $(n=2)$} \\
\hline $\begin{array}{l}\text { Feun et al. } \\
\text { (1988) }\end{array}$ & Yes $[20,41,42]$ & Case series & Unclear & $7^{\pi}$ & $\begin{array}{l}\text { - Chemotherapy regimens included a combination } \\
\text { of melphalan, dactinomycin and nitrogen mustard, } \\
\text { methotrexate, cisplatin and bleomycin, intra-arterial } \\
\text { cisplatin, adriamycin-containing regimen }\end{array}$ & {$[47]$} \\
\hline $\begin{array}{l}\text { Pectasides } \\
\text { et al. (2006) }\end{array}$ & No & Case series & $\begin{array}{l}\text { First and } \\
\text { second line }\end{array}$ & $4^{\#}$ & $\begin{array}{l}\text { - 1L: carboplatin, Etoposide (VP-16) } \\
\text { - 2L: cisplatin + ifosfamide + epirubicin }\end{array}$ & [49] \\
\hline \multicolumn{7}{|c|}{$\begin{array}{l}\text { TStudies that reported outcomes for } \geq 1 \text { type of metastases are repeated across multiple rows. } \\
\text { Fsince conducting our review, this study has been published as a full-text article [73]. } \\
\text { sOf the } 101 \text { patients included in the study, } 72 \text { had distant metastases and } 29 \text { had regional or nodal metastases. } \\
\text { "Of the } 13 \text { patients included in the study, } 6 \text { had distant metastases and } 7 \text { had regional or nodal metastases. } \\
\text { "Of the six patients included in the study, two had distant metastases and four had regional or nodal metastases. } \\
\text { ABSCT: Autologous blood stem cell transplantation; AUC: Area under the plasma concentration versus time curve; CAV: Cyclophosphamide, doxorubicin and vincristine; } \\
\text { DTIC: Dacarbazine; MCC: Merkel cell carcinoma; PEI: Cisplatin, etoposide and ifosfamide. }\end{array}$} \\
\hline
\end{tabular}

regimes compared with non-platinum-containing regimens (21 vs $17 \%$, respectively). More patients on platinum-based regimens had a PR (29\%, 4 of 14 patients) compared with non-platinum-containing regimens (17\%,
2 of 12 patients) [59-61,68]. DoR was reported in two patients to be 6 months (second-line high dose cisplatin, etoposide and ifosfamide regimen) and $10+$ months (first-line cisplatin and etoposide) $[67,68]$. 


\section{Metastatic MCC (unspecified site[s] of metastasis)}

Three studies included in our review reported outcomes in patients with unclear sites of metastases (nodal and/or distant) [41,71,72]. Similar to reported outcomes in patients with distant metastatic MCC, ORR was higher in the firstline setting (61\%; CR: 39\% and PR: 22\%) compared with second- (45\%) and third-line settings (20\%). Median DoR in the first-line setting was reported to be 8 months with mixed chemotherapy [41]. Higher ORR and CR rate were observed in patients receiving treatment with 5-fluorouracil compared with other treatments including anthracycline, cyclophosphamide or platinum-based regimens [41].

Line of therapy was unclear in the remaining two studies $[71,72]$. In one study, ORR was reported to be $60 \%$, all being PRs. Median DoR was 3 months with a combination of dacarbazine, fluorouracil and epirubicin [71]. In the second study, four patients received chemotherapy, and only one response (CR) was observed in a patient after treatment with two cycles of cyclophosphamide, vincristine and doxorubicin. However, DoR in this patient was short, lasting only for 2.3 months [72].

\section{Regional or nodal MCC}

In the retrospective study/literature review, a study conducted by Voog et al., the ORR was $69 \%$ with a median survival of 24 months among patients receiving first-line chemotherapy for regional/nodal MCC [41]. Reported OS rates were $65 \%$ at 1 year, $52 \%$ at 2 years and $35 \%$ at 4 years [41]. In the case series by Feun et al., CR was achieved in two of seven patients, PR in two of seven patients and SD in three of seven patients on chemotherapy [47]. The case series by Pectasides et al. reported that among the four patients receiving first-line therapy, two patients achieved PR, one patient achieved CR and one patient progressed. Furthermore, of these four patients, two patients received second-line therapy, of which one patient achieved PR and the other progressed [49].

\section{- Safety outcomes reported in included studies \\ Distant metastatic MCC}

Limited safety data were reported in the studies included in our review, with only 8/35 studies reporting adverse events (AEs). In the study by Iyer et al., which included 62 patients with distant metastases, 4 experienced febrile neutropenia, 3 experienced myelosuppression, sepsis was reported in 3 patients, and 1 patient experienced renal failure. Other reported AEs included fatigue, alopecia, nausea/vomiting and mucositis [39].

Specific AEs were reported in five case series $[45,50,51,53,71]$. These included alopecia in five patients, neutropenia in four patients (three being grade 3), gastrointestinal toxicity (grade 2) in two patients, while hematologic toxicity (grade 2), renal toxicity (grade 4), sepsis (grade 4), abdominal pain and paraplegia were reported in one patient each $[50,51,53,71]$.

Five studies reported death due to AEs [41,45,49,51,53]. These included the following:

- Nine deaths out of 101 patients in one study, 6 of which occurred after a doxorubicin-containing regimen. The causes of death were septic shock with febrile neutropenia (five patients) and grade 4 renal toxicity (one patient). The cause of death for the remaining three patients was not reported [41];

- Two deaths due to leukopenia out of nine patients in one study, one induced by streptozotocin fluorouracil and leucovorin and the other induced by cyclophosphamide and doxorubicin [45];

- Two of four patients in two studies (two were due to pneumonia, one following treatment with etoposide and the other with cyclophosphamide, doxorubicin, vincristine and oral prednisone) [51,53];

- Two deaths out of two patients in one study, both due to disease progression following treatment with cisplatin, ifosfamide and epirubicin [49].

We could not identify any reports of quality of life or patient-reported outcomes in MCC subjects treated with chemotherapy.

\section{Discussion}

MCC is generally considered to be a chemotherapy-sensitive tumor, but the current literature on the use of chemotherapy in patients with metastatic MCC is sparse, with most studies being case series, case reports or reviews. Of the 35 studies identified in our review assessing chemotherapy outcomes in patients with metastatic MCC, only 9 were retrospective studies/ literature reviews, with the remaining being case series and case reports. After consideration of 


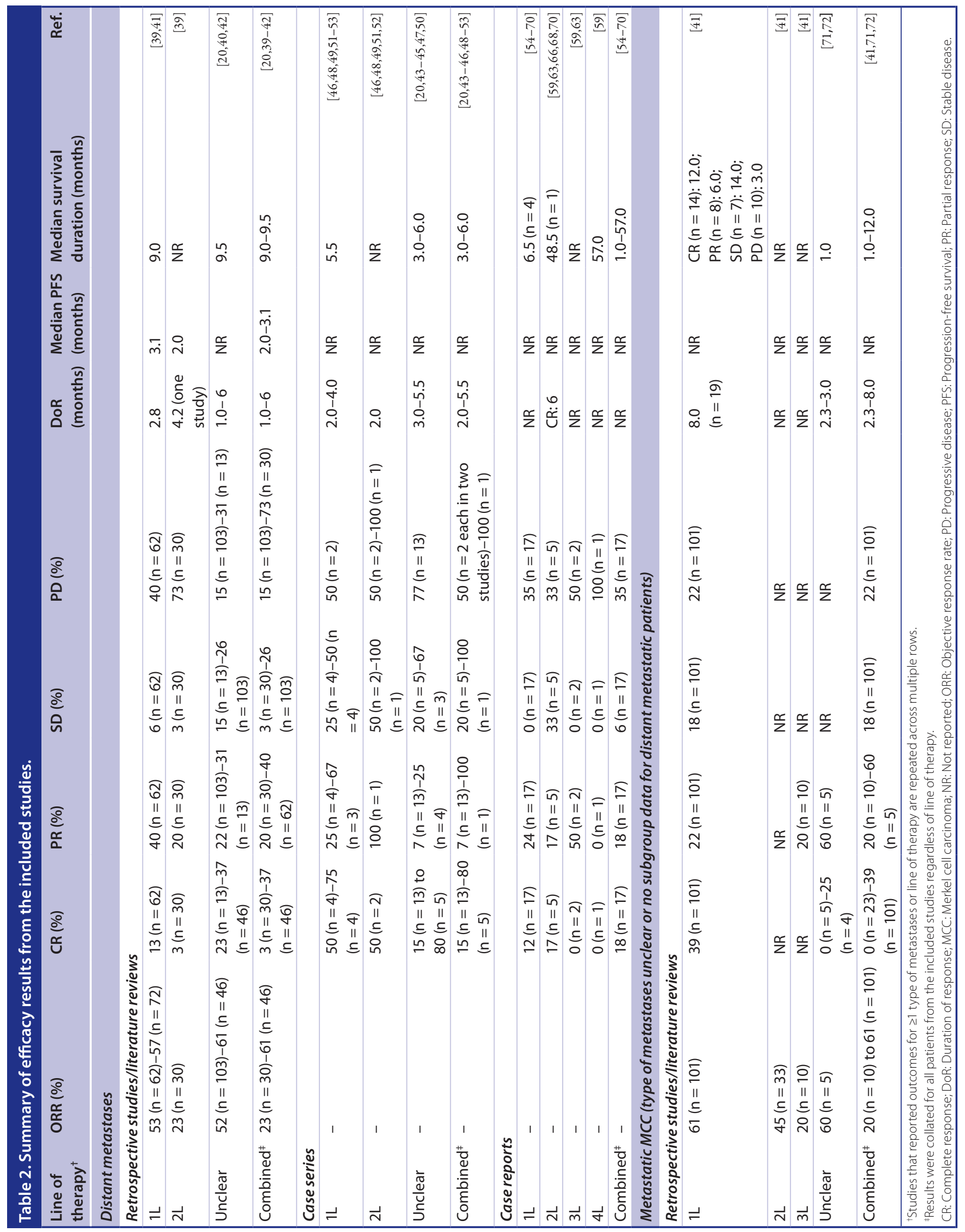




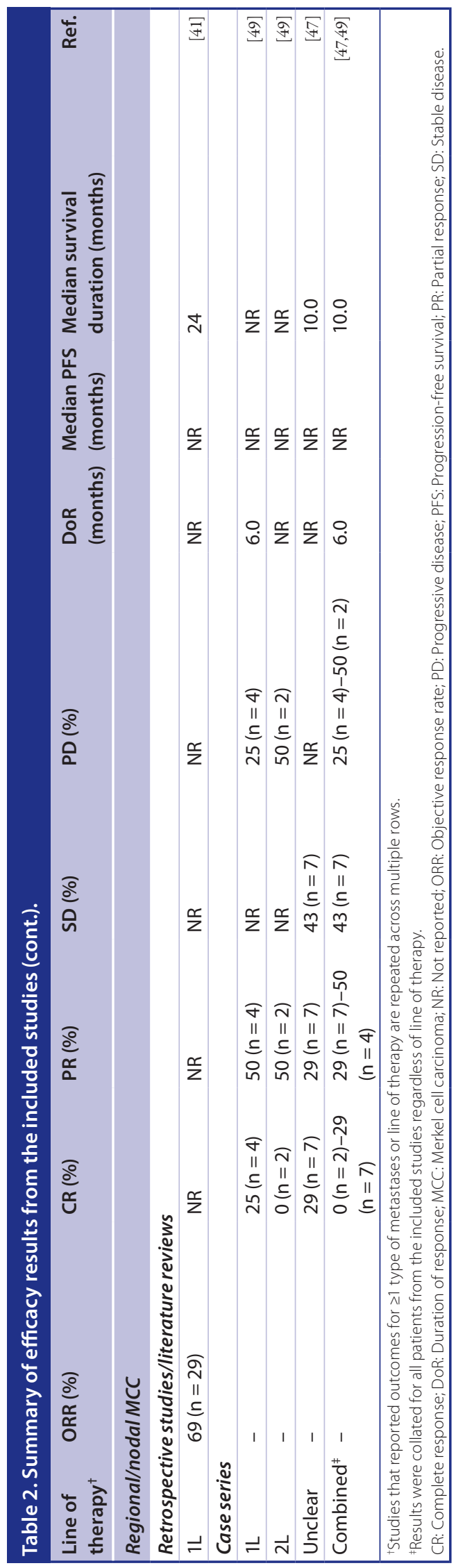

the available evidence, it is evident that patients with metastatic MCC have a poor prognosis, with frequent responses to chemotherapy but a short DoR. A limited number of studies reported efficacy results according to line of therapy; however, the available evidence suggests that response rates are higher with firstline therapy than at later lines, with a short durability of response ( $\leq 8$ months) in both the first- and second-line settings. Furthermore, the short-term tumor responses to chemotherapy are at the cost of considerable toxicities, especially hematological toxicity. Our findings are in agreement with a retrospective observational study published after the cut-off date of our review. The study used data obtained from the US Oncology Network/McKesson Specialty Health electronic health record database and medical charts between 2004 and 2014 (followup until 2015) and showed that in 20 patients with metastatic MCC receiving second- or further-line chemotherapy, response rates were low (ORR: 20\% [95\% CI: 5.7-43.7]) with brief duration (median time to treatment discontinuation: 1.5 months [95\% CI: 0.3-2.5]; median DoR: 1.7 months [95\% CI: 0.5-3.0]; PFS: 2.1 months [95\% CI: $1.0-3.2]$ ) and poor OS (median OS: 4.4 months [95\% CI: 2.2-6.2]). No patient had response lasting 6 months [74].

Since conducting our review, one of the poster presentations included has been published as a full-text manuscript [39,73], and the findings and conclusions from this study are in agreement with the findings from our review. In this retrospective study of 62 patients with distant metastatic MCC, treated with cytotoxic chemotherapy, the response rate to first-line chemotherapy was 55\% (34/62) with $13 \%$ achieving $\mathrm{CR}$ and $42 \% \mathrm{PR}$. Among responders to first-line chemotherapy, median DoR was 2.8 months. Among the 30 patients who received secondline chemotherapy, response rates were lower than those with first-line therapy (23\%) with a median DoR of 3.3 months [73].

Currently, the impact of chemotherapy on OS remains unclear. In the studies retrieved in our review, median OS was reported to be 9 [41] and 9.5 months [39] in two retrospective studies/literature reviews. A recent retrospective observational study that was published after the cut-off date of our review assessed the impact of chemotherapy in 205 patients with MCC, of which 43 patients had distant metastases. The study found that for the whole cohort, 2-year 


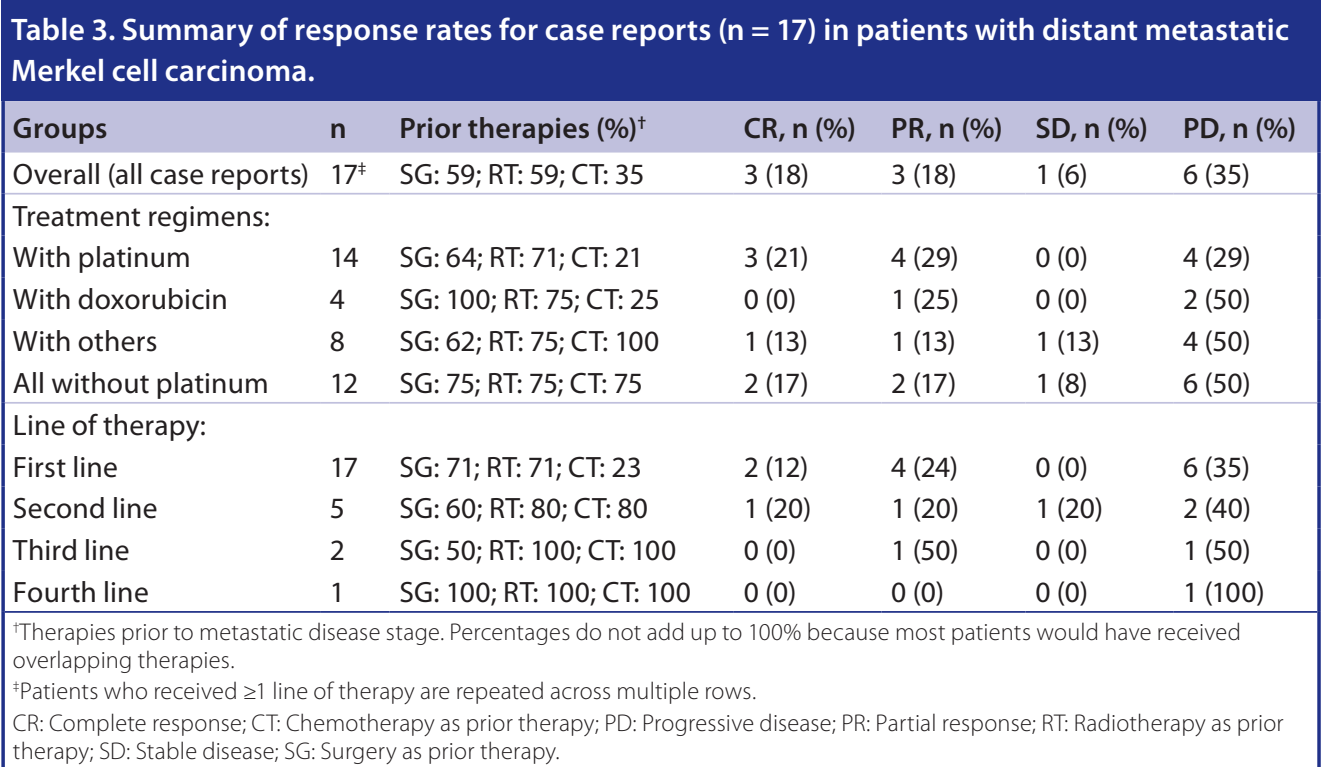

OS was not significantly increased with the use of chemotherapy ( $41 \%$ : no chemotherapy, $68 \%$ : with chemotherapy; $\mathrm{p}=0.222$ ) [75].

The current use of cytotoxic chemotherapies that rarely provide a durable response highlights the need for new, alternative treatment options. In the majority of cases, MCC appears to be an oncovirus-induced cancer, as $\mathrm{MCPyV}$ has been designated as an oncogenic virus [76]. However, the etiology of MCPyV-negative MCC may be more related to UV-induced DNA damage. In any case, UV and immunosuppression are major risk factors for developing MCC [8]. There is considerable evidence to suggest that immune system dysfunction contributes significantly to the course of MCC, implying that therapeutic agents that promote antitumor immune responses might be beneficial in MCC [77-80]. One potential mechanism contributing to tumor growth is the expression of immune-inhibitory ligands in the tumor microenvironment such as PD-L1 [81]. PD-L1 is an immune checkpoint protein that binds to its main receptor, PD-1. PD-1 is expressed by activated $\mathrm{T}$ lymphocytes and the binding of PD-L1 to PD-1 inhibits kinase signaling pathways involved in T-cell proliferation, survival and cytotoxic activity (including cytokine release), thus preventing overstimulation of immune responses [82-84]. Upregulation of PD-L1 occurs in the presence of inflammation and is observed in many tumor types, enabling tumors to avoid and escape immune surveillance. Blocking the interaction between PD-1 and PD-L1 is thought to enable the reactivation of $\mathrm{T}$ cells and the engagement of the adaptive immune system $[85,86]$. Indeed, this has already been applied in several cancer types such as advanced melanoma, head and neck squamous cell carcinoma and non-small-cell lung cancer, where both nivolumab and pembrolizumab have shown benefit in these patient populations [87-93].

PD-L1 expression has also been described in MCC tumor cells, and in tumor-infiltrating and peritumoral leukocytes [81,94], and both avelumab (MSB0010718C; anti-PD-L1) and pembrolizumab (anti-PD-1) have shown promising initial results in patients with metastatic MCC. In an ongoing, multicenter, Phase II trial of 88 patients with MCC (largest MCC trial to date), treatment with avelumab, an investigational anti-PD-L1 therapy, showed durable antitumor activity in patients with chemotherapy-refractory metastatic MCC in secondand further-line therapy. In this trial, the ORR was 32\%; 23/28 responses (82\%) were ongoing at the time of the report; the 6-month DoR was 29\%; the 6-month PFS rate was 40\%; and the 6-month OS rate was 69\%. Responses to avelumab occurred in patients with PD-L1+ and PD-L1- tumors, and MCPyV+ and MCPyVtumors [95]. Similarly, in another ongoing, multicenter, Phase II noncontrolled study in patients with previously untreated (first-line), advanced (locoregional or distant) MCC, pembrolizumab was associated with an ORR of 56\% [96], with responses in patients with $\mathrm{McPyV}+$ and $\mathrm{McPyV}$ tumors (ORRs of 62 and 44\%, respectively). The rate of PFS at 6 months was $67 \%$ [96]. 
Other immunotherapies being investigated in MCC include IL-12 and ipilimumab (cytotoxic T-lymphocyte antigen-4 inhibitor) [97,98]. These data suggest that immunotherapies have the potential to improve outcomes in patients with metastatic MCC and may provide new treatment options for this patient population.

Based on the information retrieved through this systematic literature review, a number of data gaps were identified. The literature was not consistent with the staging systems used to classify patients with MCC. A consensus staging system for MCC was introduced by the AJCC in 2010 and has since been adopted worldwide [15]. However, in the years prior to the AJCC staging system, a number of different staging systems for MCC had been published, all of which were based on cohorts of fewer than 300 cases and derived from 3 or fewer institutions, with a number of discrepancies among the different staging systems [14,99-102]. This has made comparisons between studies challenging.

A limited number of studies included in our review reported data specific to first-line or second-line therapy. Therefore, it was difficult to draw any comparisons relating to the efficacy of interventions according to line of therapy. In addition, across the retrospective studies/ literature reviews that evaluated patients with distant metastases, three were also literature reviews $[20,41,42]$. Hence, there is an evident risk of bias associated with selection of studies and selective reporting of results, as well as double counting studies that were included in the previous reviews $[20,41,42]$. Moreover, the evidence retrieved from most of the included studies was

\section{EXECUTIVE SUMMARY}

Merkel cell carcinoma is a rare, aggressive \& immunogenic skin cancer

- Merkel cell carcinoma (MCC) is a rare neuroendocrine, cutaneous malignancy, which occurs more frequently in elderly individuals, exhibits aggressive clinical features and is associated with a poor prognosis.

- The etiology of MCC is likely multifactorial, with immunosuppression, ultraviolet-induced skin damage, and viral factors (Merkel cell polyomavirus) contributing to disease development.

- MCC may grow rapidly on chronically sun-exposed skin, and once MCC develops, distant metastases typically arise within the first 3 years following diagnosis.

\section{Currently, there are no approved treatment options for patients with metastatic MCC}

- Treatment has been primarily limited to chemotherapy or investigational therapies.

- The literature on the use of chemotherapy in advanced/metastatic MCC is inadequate to definitively assess whether chemotherapeutic regimens improve either progression-free survival or overall survival (OS) in patients with MCC, and thus their routine use in MCC cannot be recommended on the basis of the current evidence.

\section{Outcomes with chemotherapy in patients with metastatic MCC are poor}

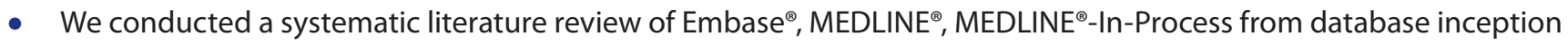
to January 2016 to capture efficacy, health-related quality of life, and safety/tolerability outcomes of systemic interventions in patients with metastatic MCC.

- The database search retrieved 3425 citations, of which 35 met the inclusion criteria. Of these, 33 studies included patients with distant metastases, 3 with metastatic MCC not differentiating between distant and locoregional diseases, and 3 studies with regional metastases.

- Most of the studies were case series/case reports.

- Across all included studies, response rates ranged from 20 to $61 \%$, with higher response rates in the first-line setting (53-61\%) compared with second-line setting (23-45\%).

- Among responders, duration of response was short ( $\leq 8$ months) in both the first- and second-line settings.

\section{Conclusion}

- The literature on the use of chemotherapy in patients with metastatic MCC is sparse.

- Although initial responses to chemotherapy were reported, duration of response was short.

- There is a need for novel agents that can induce durable responses in metastatic MCC. 
based on small sample sizes (as small as two patients) with variability in the chemotherapy regimens assessed, making it difficult to establish any differences in outcomes between lines of therapy and chemotherapy regimens. This highlights the need for robust trials in this patient population. There was also variability in defining response rate across the included studies; only four studies assessed response based on RECIST criteria, while this was unclear in the majority of studies $[39,40,51,59]$. Finally, limited data on safety outcomes were reported across the included studies, and no studies reported data on HRQoL among patients with metastatic MCC.

\section{Future perspective}

With emerging clinical data for checkpoint inhibitors in MCC, we believe that immunotherapies have the potential to improve outcomes in patients with metastatic MCC and may provide new treatment options for this patient population in the future.

\section{Conclusion}

The findings of this comprehensive literature review suggest that irrespective of the type of metastases, outcomes with chemotherapy regimens in patients with MCC are poor. However, reported response rates to first-line chemotherapy were better compared with second-line chemotherapy. Still, DoR to chemotherapy regimens was short in both the first- and second-line settings with disease recurring in most patients by 6 months. The chemotherapy regimens evaluated in the included studies provided limited benefit with respect to OS and were associated with considerable toxicities, highlighting the need for new treatment options that can induce durable responses in patients with metastatic MCC.

\section{Financial \& competing interests disclosure}

$M$ Bharmal, L Mahnke and H Phatak are employees of Merck KGaA/EMD Serono. P Nghiem is a paid consultant for EMD Serono. JC Becker is a paid consultant for EMD Serono, Pfizer and BMS, and he has received research grants from EMD Serono and BMS. This study was sponsored by Merck KGaA, Darmstadt, Germany and EMD Serono, USA (a US subsidiary of Merck KGaA, Darmstadt, Germany) and is part of an alliance between Merck KGaA and Pfizer, Inc. The authors have no other relevant affiliations or financial involvement with any organization or entity with a financial interest in or financial conflict with the subject matter or materials discussed in the manuscript apart from those disclosed.

Medical writing support was provided by S Mardiguian, PAREXEL International, London, UK, and was funded by Merck KGaA, Darmstadt, Germany and Pfizer, Inc.

\section{Open access}

This work is licensed under the AttributionNonCommercial-NoDerivatives 4.0 Unported License. To view a copy of this license, visit http://creativecommons.org/ licenses/by-nc-nd/4.0/

\section{References}

Papers of special note have been highlighted as:

- of interest; $\bullet \bullet$ of considerable interest

1 Toker C. Trabecular carcinoma of the skin. Arch. Dermatol. 105(1), 107-110 (1972).

2 Saini AT, Miles BA. Merkel cell carcinoma of the head and neck: pathogenesis, current and emerging treatment options. Onco. Targets Ther. 8, 2157-2167 (2015).

3 Chen MM, Roman SA, Sosa JA, Judson BL. The role of adjuvant therapy in the management of head and neck Merkel cell carcinoma: an analysis of 4815 patients. JAMA Otolaryngol. Head Neck Surg. 141(2), 137-141 (2015).

4 Smith VA, Camp ER, Lentsch EJ. Merkel cell carcinoma: identification of prognostic factors unique to tumors located in the head and neck based on analysis of SEER data. Laryngoscope 122(6), 1283-1290 (2012).
5 Lemos BD, Storer BE, Iyer JG et al. Pathologic nodal evaluation improves prognostic accuracy in Merkel cell carcinoma: analysis of 5823 cases as the basis of the first consensus staging system. J. Am. Acad. Dermatol. 63(5), 751-761 (2010).

6 Arora R, Chang Y, Moore PS. MCV and Merkel cell carcinoma: a molecular success story. Curr. Opin. Virol. 2(4), 489-498 (2012).

7 Becker JC, zur HA. Cells of origin in skin cancer. J. Invest. Dermatol. 134(10), 2491-2493 (2014).

8 Poulsen M. Merkel cell carcinoma of skin: diagnosis and management strategies. Drugs Aging 22(3), 219-229 (2005).

9 Feng H, Shuda M, Chang Y, Moore PS. Clonal integration of a polyomavirus in human Merkel cell carcinoma. Science 319(5-6), 1096-1100 (2008).
10 Harms PW, Vats P, Verhaegen ME et al. The distinctive mutational spectra of polyomavirus-negative Merkel cell carcinoma. Cancer Res. 75(18), 3720-3727 (2015).

11 Wong SQ, Waldeck K, Vergara IA et al. UV-associated mutations underlie the etiology of MCV-negative Merkel cell carcinomas. Cancer Res. 75(24), 5228-5234 (2015).

12 Goh G, Walradt T, Markarov V et al. Mutational landscape of MCPyV-positive and MCPyV-negative Merkel cell carcinomas with implications for immunotherapy. Oncotarget 7(3), 3403-3415 (2016).

13 Heath M, Jaimes N, Lemos B et al. Clinical characteristics of Merkel cell carcinoma at diagnosis in 195 patients: the AEIOU features. J. Am. Acad. Dermatol. 58(3), 375-381 (2008).

14 Allen PJ, Bowne WB, Jaques DP, Brennan MF, Busam K, Coit DG. Merkel cell 
carcinoma: prognosis and treatment of patients from a single institution. J. Clin. Oncol. 23(10), 2300-2309 (2005).

15 Edge S, Byrd DR, Compton CC, Fritz AG, Greene FL, Trotti A. AJCC Cancer Staging Manual (7th Edition). 315-323 Springer International Publishing, NY, USA (2010).

16 Harms KL, Healy MA, Nghiem P et al. Analysis of prognostic factors from 9387 Merkel cell carcinoma cases forms the basis for the new 8th edition AJCC staging system. Ann. Surg. Oncol. 23(11), 3564-3571 (2016).

17 Aldabagh B, Joo J, Yu SS. Merkel cell carcinoma: current status of targeted and future potential for immunotherapies. Semin. Cutan. Med. Surg. 33(2), 76-82 (2014).

18 NCCN. Merkel cell carcinoma guidelines, Version I. www.nccn.org/professionals/physician_gls

19 Lebbe C, Becker JC, Grob JJ et al. Diagnosis and treatment of Merkel cell carcinoma. European consensus-based interdisciplinary guideline. Eur. J. Cancer 51(16), 2396-2403 (2015).

20 Tai PT, Yu E, Winquist E et al. Chemotherapy in neuroendocrine/Merkel cell carcinoma of the skin: case series and review of 204 cases. J. Clin. Oncol. 18(12), 2493-2499 (2000).

- A literature review and a case series on chemotherapy outcomes in patients with metastatic Merkel cell carcinoma (MCC).

21 Bhatia S, Afanasiev O, Nghiem P. Immunobiology of Merkel cell carcinoma: implications for immunotherapy of a polyomavirus-associated cancer. Curr. Oncol. Rep. 13(6), 488-497 (2011).

22 Santamaria-Barria JA, Boland GM, Yeap BY, Nardi V, Dias-Santagata D, Cusack JC Jr. Merkel cell carcinoma: 30 year experience from a single institution. Ann. Surg. Oncol. 20(4), 1365-1373 (2013).

23 The Cochrane Database of Systematic Reviews. www.cochranelibrary.com/cochranedatabase-of-systematic-reviews/

24 Database of Abstracts of Reviews of Effects. http://community.cochrane.org/

25 Orphanet website. www.orpha.net/consor/cgi-bin/index.php

26 GLOBOCAN. http://globocan.iarc.fr/Default.aspx

27 Embase.

Embase.com

28 American Academy of Dermatology. www.aad.org/
29 American Head and Neck Society. www.ahns.info/

30 American Society of Clinical Oncology. www.asco.org/

31 British Association of Dermatologists. www.bad.org.uk/

32 European Association of Dermato Oncology. www.eado.org/

33 European Society for Medical Oncology. www.esmo.org/

34 European Cancer Congress. www.eccocongress.org/

35 International Federation of Head and Neck Oncologic Societies. www.ifhnos.org/home

36 International Society for Pharmacoeconomics and Outcomes Research. www.ispor.org/

37 The Society for Melanoma Research. www.societymelanomaresearch.org/

38 World Congress of Dermatology. http://derm2015.org/

39 Iyer JG, Blom A, Doumani R, Lewis C, Ma C. Response rate and durability of chemotherapy for metastatic Merkel cell carcinoma among 62 patients. Presented at: The American Society of Clinical Oncology (ASCO) Annual Meeting. Chicago, IL, USA, 30 May-3 June 2014.

40 Satpute S, Ammakkanavar NR, Einhorn LH. Role of platinum-based chemotherapy for Merkel cell tumor in adjuvant and metastatic settings. Presented at: The American Society of Clinical Oncology (ASCO) Annual Meeting. Chicago, IL, USA, 30 May-3 June 2014

41 Voog E, Biron P, Martin JP, Blay JY. Chemotherapy for patients with locally advanced or metastatic Merkel cell carcinoma. Cancer 85(12), 2589-2595 (1999).

- A literature review and a case series on chemotherapy outcomes in patients with metastatic MCC.

42 Sharma D, Flora G, Grunberg SM. Chemotherapy of metastatic Merkel cell carcinoma: case report and review of the literature. Am. J. Clin. Oncol. 14(2), 166-169 (1991).

- A literature review and a case report on chemotherapy outcomes in patients with metastatic MCC.

43 Bourne RG, O'Rourke MG. Management of Merkel cell tumour. Aust. N. Z. J. Surg. 58(12), 971-974 (1988).

44 Boyle F, Pendlebury S, Bell D. Further insights into the natural history and management of primary cutaneous neuroendocrine (Merkel cell) carcinoma. Int. J. Radiat. Oncol. Biol. Phys. 31(2), 315-323 (1995).

45 Crown J, Lipzstein R, Cohen $\mathrm{S}$ et al. Chemotherapy of metastatic Merkel cell cancer. Cancer Invest. 9(2), 129-132 (1991).

46 Fenig E, Lurie H, Sulkes A. The use of cyclophosphamide, methotrexate, and 5-fluorouracil in the treatment of Merkel cell carcinoma. Am. J. Clin. Oncol. 16(1), 54-57 (1993).

47 Feun LG, Savaraj N, Legha SS, Silva EG, Benjamin RS, Burgess MA. Chemotherapy for metastatic Merkel cell carcinoma. Review of the M. D. Anderson Hospital's experience. Cancer 62(4), 683-685 (1988).

48 Grosh WW, Giannone L, Hande KR, Johnson DH. Disseminated Merkel cell tumor. Treatment with systemic chemotherapy. Am. J. Clin. Oncol. 10(3), 227-230 (1987)

49 Pectasides D, Pectasides M, Psyrri A et al. Cisplatin-based chemotherapy for merkel cell carcinoma of the skin. Cancer Invest. 24(8), 780-785 (2006).

50 Redmond J III, Perry J, Sowray P, Vukelja SJ, Dawson N. Chemotherapy of disseminated Merkel-cell carcinoma. Am. J. Clin. Oncol. 14(4), 305-307 (1991).

51 Schlaak M, Podewski T, Von BW et al. Induction of durable responses by oral etoposide monochemotherapy in patients with metastatic Merkel cell carcinoma. Eur. J. Dermatol. 22(2), 187-191 (2012).

52 Tai P, Assouline A, Joseph K, Lian JD, Krzisch C. Salvage treatments for Merkel cell carcinoma of skin. Nowotwory J. Onccology 61(6), 548-553 (2011).

53 Wynne CJ, Kearsley JH. Merkel cell tumor. A chemosensitive skin cancer. Cancer 62(1), 28-31 (1988).

54 Barkdull GC, Healy JF, Weisman RA. Intracranial spread of Merkel cell carcinoma through intact skull. Ann. Otol. Rhinol. Laryngol. 113(9), 683-687 (2004).

55 Biver-Dalle C, Nguyen T, Touze A et al. Use of interferon-alpha in two patients with Merkel cell carcinoma positive for Merkel cell polyomavirus. Acta Oncol. 50(3), 479-480 (2011).

56 Calza L, Beltrami C, Manfredi R, Colangeli V, Freo E, Chiodo F. Merkel cell carcinoma in a human immunodeficiency virus-infected patient. Br. J. Dermatol. 146(5), 895-898 (2002).

57 Chang DT, Mancuso AA, Riggs CE Jr, Mendenhall WM. Merkel cell carcinoma of 
the skin with leptomeningeal metastases. Am. J. Otolaryngol. 26(3), 210-213 (2005).

58 Cusick L, Refsum SE. Merkel cell carcinoma of the breast: report of a case and review of the literature. Ulster Med. J. 73(2), 137-138 (2004).

59 Davids MS, Charlton A, Ng SS et al. Response to a novel multitargeted tyrosine kinase inhibitor pazopanib in metastatic Merkel cell carcinoma. J. Clin. Oncol. 27(26), e97-e100 (2009).

60 Gaba S, Chopra P, Pankaj P, Belho ES, Qadri $\mathrm{AB}$, Aggarwal S. Merkel cell carcinoma - a rare cause of non-healing skin ulcer: a case report. J. Indian Med. Assoc. 110(7), 496-498 (2012).

61 Grenader T, Shavit L. Tumor lysis syndrome in a patient with Merkel cell carcinoma and provoked pathologic sequence of acute kidney injury, reduced clearance of carboplatin and fatal pancytopenia. Onkologie 34(11), 626-629 (2011).

62 Krejci K, Tomas T, Pavel H, Hana C, Marián $\mathrm{H}$. Merkel cell carcinoma of the gluteal region with ipsilateral metastasis into the pancreatic graft of a patient after combined kidneypancreas transplantation. Onkologie 33(10), 520-524 (2010).

63 Noell CM, Rose E, Nesbitt LT. Merkel cell carcinoma presenting as right leg edema in a multiple myeloma patient. J. Am. Acad. Dermatol. 71(2), e50-e52 (2014).

64 Orlova K, Markovich A, Orel N, Demidov L. Role of somatostatin analogues in the management of Merkel cell carcinoma: a case report. Presented at: The 9th Annual European Neuroendocrine Tumor Society Conference for the Diagnosis and Treatment of Neuroendocrine Tumor Disease. Copenhagen, Denmark, 7-9 March 2012.

65 Santos-Juanes J, Palomo C, Rodrigo L, Fernandez-Vega I. Anaemia due to gastric haemorrhage by a metastatic Merkel cell carcinoma. Prz. Gastroenterol. 10(4), 244-246 (2015).

66 Shah JM, Sundar G, Tan KB, Zee YK. Unusual Merkel cell carcinoma of the eyelid. Orbit 31(6), 425-427 (2012).

67 Tanemura A, Nakano M, Iwasaki T et al. An extremely rare case of Merkel cell carcinoma metastasized to the duodenum. Eur. J. Dermatol. 22(4), 568-570 (2012).

68 Waldmann V, Goldschmidt H, Jackel A et al. Transient complete remission of metastasized Merkel cell carcinoma by high-dose polychemotherapy and autologous peripheral blood stem cell transplantation. $B r$. J. Dermatol. 143(4), 837-839 (2000).
69 Wang LW, Walker BD, Omari A, Tay AE, Subbiah RN. Metastatic Merkel cell carcinoma of the heart. Eur. Heart J. 35(41), 2927 (2014).

70 Yamana N, Sueyama H, Hamada M. Cardiac metastasis from Merkel cell skin carcinoma. Int. J. Clin. Oncol. 9(3), 210-212 (2004).

71 Di BM, Bajetta E, Bochicchio AM et al. A Phase II trial of dacarbazine, fluorouracil and epirubicin in patients with neuroendocrine tumours. A study by the Italian trials in medical oncology (I. T.M. O.) Group. Ann. Oncol. 6(1), 77-79 (1995).

72 Savage P, Constenla D, Fisher C, Thomas JM, Gore ME. The natural history and management of Merkel cell carcinoma of the skin: a review of 22 patients treated at the Royal Marsden Hospital. Clin. Oncol. (R. Coll. Radiol.) 9(3), 164-167 (1997).

73 Iyer JG, Blom A, Doumani R et al. Response rates and durability of chemotherapy among 62 patients with metastatic Merkel cell carcinoma. Cancer Med. 5(9), 2294-2301 (2016).

- An important and one of the largest observational studies on the durability of chemotherapy regimens in patients with metastatic MCC.

74 Cowey LC, Mahnke L, Espirito J et al. Real-world outcomes of patients with metastatic Merkel cell carcinoma treated with second-line or later chemotherapy in a community oncology setting in the United States (2016). www.ispor.org/research_pdfs/54/

75 Sabol AJ, Markovic S, Otley C, Price KAR. Benefit of chemotherapy (CT) in patients (pts) with Merkel cell carcinoma (MCC) with distant metastases (mets) and visceral organ involvement. J. Clin. Oncol. 34(Suppl.), Abstract e21000 (2016).

76 IARC Working Group on the Evaluation of Carcinogenic Risks to Humans. Malaria and some polyomaviruses (SV40, BK, JC, and Merkel cell viruses). IARC Monogr. Eval. Carcinog. Risks Hum. 104, 9-350 (2014).

77 Paulson KG, Iyer JG, Blom A et al. Systemic immune suppression predicts diminished Merkel cell carcinoma-specific survival independent of stage. J. Invest. Dermatol. 133(3), 642-646 (2013).

78 Paulson KG, Iyer JG, Simonson WT et al. $\mathrm{CD}^{+}$lymphocyte intratumoral infiltration as a stage-independent predictor of Merkel cell carcinoma survival: a population-based study. Am. J. Clin. Pathol. 142(4), 452-458 (2014).

79 Sihto H, Bohling T, Kavola H et al. Tumor infiltrating immune cells and outcome of
Merkel cell carcinoma: a population-based study. Clin. Cancer Res. 18(10), 2872-2881 (2012).

80 Behr DS, Peitsch WK, Hametner C et al. Prognostic value of immune cell infiltration, tertiary lymphoid structures and PD-L1 expression in Merkel cell carcinomas. Int. J. Clin. Exp. Pathol. 7(11), 7610-7621 (2014).

81 Lipson EJ, Vincent JG, Loyo M et al. PD-L1 expression in the Merkel cell carcinoma microenvironment: association with inflammation, Merkel cell polyomavirus and overall survival. Cancer Immunol. Res. 1(1), 54-63 (2013).

82 Postow MA, Callahan MK, Wolchok JD. Immune checkpoint blockade in cancer therapy. J. Clin. Oncol. 33(17), 1974-1982 (2015).

83 Santarpia M, Karachaliou N. Tumor immune microenvironment characterization and response to anti-PD-1 therapy. Cancer Biol. Med. 12(2), 74-78 (2015).

84 Zitvogel L, Kroemer G. Targeting PD-1/ PD-L1 interactions for cancer immunotherapy. Oncoimmunology 1(8), 1223-1225 (2012).

85 Boyerinas B, Jochems C, Fantini M et al. Antibody-dependent cellular cytotoxicity activity of a novel anti-PD-L1 antibody avelumab (MSB0010718C) on human tumor cells. Cancer Immunol. Res. 3(10), 1148-1157 (2015).

86 Philips GK, Atkins M. Therapeutic uses of anti-PD-1 and anti-PD-L1 antibodies. Int. Immunol. 27(1), 39-46 (2015).

87 Topalian SL, Hodi FS, Brahmer JR et al. Safety, activity, and immune correlates of anti-PD-1 antibody in cancer. $N$. Engl. J. Med. 366(26), 2443-2454 (2012).

88 Brahmer J, Reckamp KL, Baas P et al. Nivolumab versus docetaxel in advanced squamous-cell non-small-cell lung cancer. N. Engl. J. Med. 373(2), 123-135 (2015).

89 Garon EB, Rizvi NA, Hui R et al. Pembrolizumab for the treatment of non-small-cell lung cancer. $N$. Engl. J. Med. 372(21), 2018-2028 (2015).

90 Ribas A, Puzanov I, Dummer R et al. Pembrolizumab versus investigator-choice chemotherapy for ipilimumab-refractory melanoma (KEYNOTE-002): a randomised, controlled, Phase II trial. Lancet Oncol. 16(8), 908-918 (2015).

91 Robert C, Long GV, Brady B et al. Nivolumab in previously untreated melanoma without BRAF mutation. N. Engl. J. Med. 372(4), 320-330 (2015). 
92 No authors listed. Nivolumab Doubles Survival for Patients with HNSCC. Cancer Discov. 6(7), OF3 (2016).

93 Addeo R, Caraglia M, Iuliano G. Pembrolizumab: the value of PDL1 biomarker in head and neck cancer. Expert Opin. Biol. Ther. 16(9), 1075-1078 (2016).

94 Afanasiev OK, Yelistratova L, Miller N et al. Merkel polyomavirus-specific T cells fluctuate with merkel cell carcinoma burden and express therapeutically targetable PD-1 and Tim-3 exhaustion markers. Clin. Cancer Res. 19(19), 5351-5360 (2013).

95 Kaufman HL, Russell J, Hamid O et al. Avelumab in patients with chemotherapyrefractory metastatic Merkel cell carcinoma: a multicentre, single-group, open-label, Phase II trial. Lancet Oncol. 17(10), 1374-1385 (2016).
-• An important trial on the efficacy of avelumab, an investigational programmed death ligand-1 inhibitor, for the treatment of patients with metastatic MCC.

96 Nghiem PT, Bhatia S, Lipson EJ et al. PD-1 blockade with pembrolizumab in advanced Merkel-cell carcinoma. N. Engl. J. Med. 374(26), 2542-2552 (2016).

-• An important trial on the efficacy of pembrolizumab, an investigational programmed death-1 inhibitor, for the treatment of patients with advanced MCC.

97 Clinical Trials Database: NCT02196961. https.//clinicaltrials. gov/ct2

98 Bhatia S, Iyer I, Ibrani D et al.E. Intratumoral delivery of Interleukin-12 DNA via in vivo electroporation leads to regression of injected and non-injected tumors in Merkel cell carcinoma. Final results of a Phase II study. E. Congress Annual Meeting J. Cancer 51(supplement 3), Abstract 504.

99 Allen PJ, Zhang ZF, Coit DG. Surgical management of Merkel cell carcinoma. Ann. Surg. 229(1), 97-105 (1999).

100 Clark JR, Veness MJ, Gilbert R, O’Brien CJ, Gullane PJ. Merkel cell carcinoma of the head and neck: is adjuvant radiotherapy necessary? Head Neck 29(3), 249-257 (2007).

101 Greene FL, Page DL, Fleming ID et al. AJCC Cancer Staging Manual (6th Edition). Springer International Publishing, NY, USA (2002).

102 Yiengpruksawan A, Coit DG, Thaler HT, Urmacher C, Knapper WK. Merkel cell carcinoma. Prognosis and management. Arch. Surg. 126(12), 1514-1519 (1991). 